\title{
Feeds with Probiotics in Animals' Nutrition
}

\author{
Joanna Biernasiak ${ }^{1}$, Katarzyna Śliżewska ${ }^{2}$ and Zdzisława Libudzisz ${ }^{2}$ \\ ${ }^{1}$ Institute of Chemical Technology of Food, Technical University of Lodz \\ ${ }^{2}$ Institute of Fermentation Technology and Microbiology, Technical University of Lodz \\ Poland
}

\section{Introduction}

The discovery of penicillin by Alexander Fleming in 1928 was a turning point which fundamentally revolutionized human and veterinary medicine. Antibiotics in veterinary medicine have been used to prevent and control bacterial infections and as growth promoters. Prevention and control of bacterial infections have been achieved by a therapeutic, metaphylactic or prophylactic application of antibiotics. Therefore, the substances, predominantly of the same class as in human medicine, have been used in veterinary medicine. Antibiotics regularly administered to animals in order to improve their growth, to better the use of feed and to reduce the number of falls have been defined as antibiotic growth promoters. The use of AGP in the European Union was approved by the Council Directive of 23 November 1970 concerning feed additives (70/524/EEC).

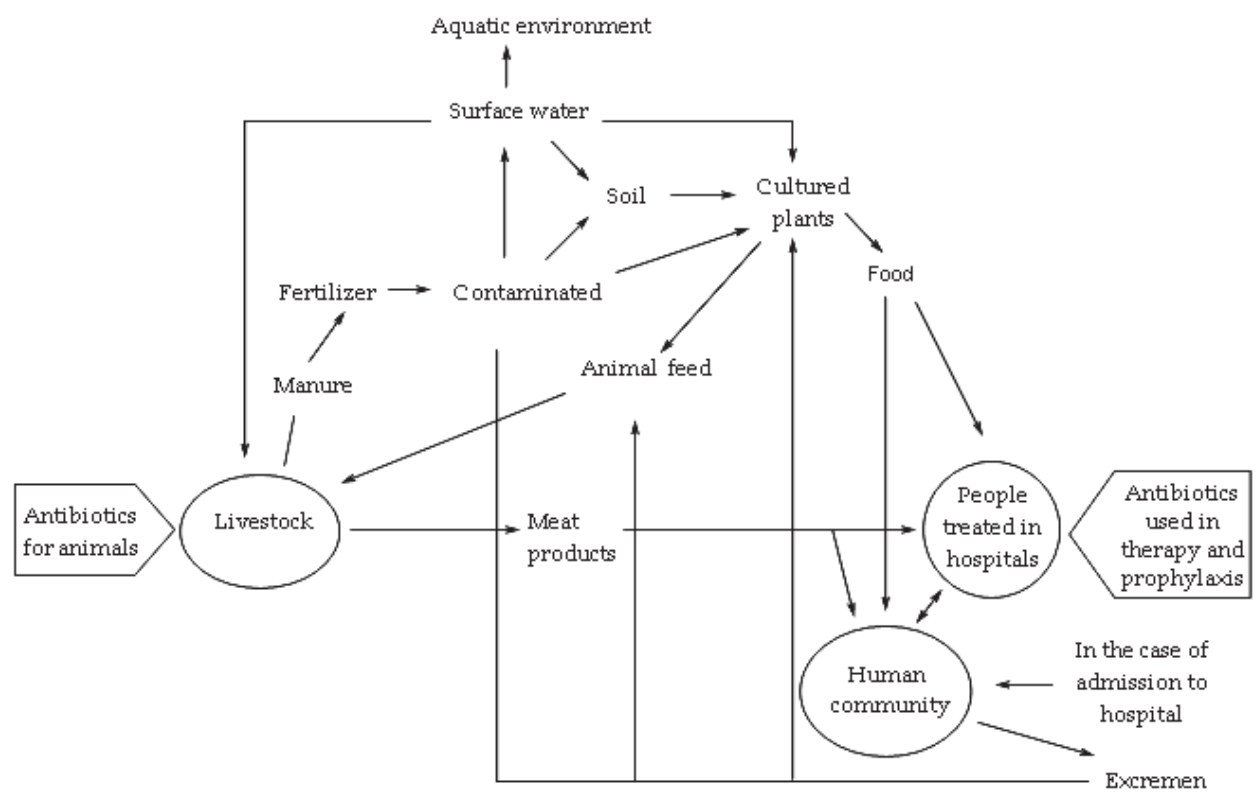

Fig. 1. Routes of spread of antibiotic-resistant strains of bacteria and drug resistance genes 
The use of additives in feed has caused a number of negative changes. It influenced, among others, the environmental degradation and development of drug resistance in bacteria. Livestock are a major reservoir of bacteria resistant to antibiotics. These pathogens contained in animal meet entered human body and quickly spread in human society. Resistant bacteria also spread thanks to the use of manure as natural fertilizer. Such fertilizer, rich in drug-resistant bacteria, contaminated water and soil which had direct contact with grown plants presenting food both for humans and animals. The routs of spreading of antibiotic-resistant strains of bacteria are shown in Figure 1 (Witte, 2000).

For this reason, the number of kinds of antibiotics approved for use in animal nutrition have been consistently limited.

Beginning from 1 January 2006, the European Union introduced a total ban on the application of antibiotic growth promoters in feeds for animals bred for consumption. The ban was introduced at the same time in all countries of the Union. Since that time, antibiotics have been allowed to be used as drugs only in medicinal animal feeds or in prophylactic additives. The Regulation EC No 1831/2003 of the European Parliament and Council dated 22 August 2003, on the additives used in animal nutrition, includes, among others, probiotics as feed additives alternative to antibiotic growth promoters (Casewell et al. 2003; Berghmann et al., 2005).

\section{Definition of the term "probiotic"}

It is most probable that it was Ferdinand Vergin who introduced the term "probiotic" in 1954, when, in an article entitled "Anti und Probiotika" he compared the detrimental effect exerted on the flora by antibiotics and other antimicrobial substances with positive impact („Probiotika”) induced by beneficial bacteria. A few years later, in 1965, Lilly \& Stillwell described probiotics as microorganisms stimulating the growth of other microorganisms. In 1974, Parker used this term for organisms and substances that contribute to balancing the intestinal microflora of the host. The definition currently in use was proposed by $\mathrm{FAO} / \mathrm{WHO}$ in 2002. It defines probiotics as live microorganisms which when administered in adequate amounts provide health benefits to the host. The microorganisms used in animal nutrition in the European Union include mainly Gram-positive bacteria that belong to the genus Bacillus (B. cereus, B. licheniformis, B. subtilis), Enterococcus (E. faecium), Lactobacillus (L. acidophilus, L. casei, L. farciminis, L. plantarum, L. rhamnosus), Pediococcus (P. acidilactici), Streptococcus (S. infantarius), and yeasts of the genus Saccharomyces (S. cerevisiae and S. boulardii) (Anadón et al., 2006). Saccharomyces boulardii is a non-pathogenic yeast described in clinical literature as a biotherapeutical factor. According to taxonomic research, $S$. boulardii is considered to be a variation within the species S. cerevisiae, and in accordance with the agreed taxonomy it should be referred to as $S$. cerevisiae var. boulardii (Mitterdorfer et al., 2002; Van der Kühle, 2005). In contrast to bacteria of the genus Bacillus and yeasts of the genus Saccharomyces, Lactobacillus and Enterococcus bacteria belong to typical intestinal animal microflora and are present in large quantities, i.e. respectively $10^{7}-10^{8}$ and $10^{5}-10^{6}$ $\mathrm{CFU} / \mathrm{g}$ in the intestinal content (Anadón et al., 2006).

\section{Procedures of probiotics evaluation}

According to the Commission Directive 94/40/EC of 22 July 1994 setting out procedures for the assessment of additives, including microorganisms used in animal nutrition, results should be presented concerning mainly the following areas: 
1. Identification, characteristics, conditions of use and methods of control of the additive In case of microorganisms it is necessary to provide:

- name and taxonomic description in accordance with the International Code of Nomenclature

- $\quad$ name and place of culture collection and number of deposit

- genetic modification and all relevant characteristics for its identification

- $\quad$ origin

- genetic stability and purity of the cultivated strains

- $\quad$ properties relevant for the identification and proposed usage (e.g. vegetative form or sporulated form, $\mathrm{CFU} / \mathrm{g}$ )

- resistance (loss of biological activity, e.g. viability): to weather activity (storage duration), during the preparation of premixes and feed (possible degradation products), to storage of premixes and feed in certain defined conditions (storage duration).

2. Effectiveness of the additive

In case of microorganisms it is necessary to provide:

- information about the effects on: the nutritional value, the growth of animals, animal product features and their effectiveness, animal welfare and other parameters having a positive impact on animal production

- conditions for conducting experiments on animals. The test performed must be described, along with the statistical assessment and the methods used. The description must include the following data:

- $\quad$ species, breed, age and sex of animals (the method of identification)

- the test number and the number of experimental groups together with the number of animals in each of them

- the level of content of microorganism(s) in feed established by a control analysis with the use of a relevant approved method

- the place where the test was carried out, together with the description of health, physiological, nutritional and breeding conditions in accordance with the standard practice in the Community

- the date and exact duration of testing

- side effects and other negative effects which occurred during the experiment and the time when they were observed.

3. Additive safety.

In case of microorganisms it is necessary to:

- demonstrate the lack of pathogenicity and toxicity in relation to the target species and humans under the anticipated conditions of use

- identify the antibiotic resistance

- present the results of tolerance tests in the target species. In the case of genetically modified organisms (GMO), in the understanding of Article 2 item 1 and 2 of Council Directive 90/220/EEC, the following information must be provided:

- a copy of the written consent of the competent authorities to the deliberate release of genetically modified organisms for the sake of research and development in accordance with Article 6 item 4 of Directive 90/220/EEC, and a summary of the notification, as specified in Article 9 of Directive 90/220/EEC

- complete technical documentation with information required in Annex 2 to Directive $90 / 220 / E E C$, extended, if necessary, with the data on the variety of use of the additive, including the information on the data and results obtained based on the releases of 
GMOs, conducted for the sake of research and development and concerning ecosystems that might be affected by the use of the additive, and also a risk assessment in respect of human and animal health and the environment in connection with the genetically freed organism contained in the product, including the information obtained from the current stage of research and development concerning the influence of the GMO release on human health and the environment.

- conditions of introducing the additive on the market, including special conditions of use and transport, as well as a proposal for labeling and packaging, which should at least comprise the requirements set out in Annex III to Directive 90/220/EEC

\section{Activity of probiotic microorganisms}

The mechanism of the impact of probiotics on animals has not been fully elucidated and is still under investigation. According to the literature data, the proposed operation mechanisms of probiotic strains are as follows:

\subsection{Maintenance of microbiological balance in alimentary tract}

Maintenance of microbiological balance, the so-called eubiosis in the alimentary tract. The alimentary tract of animals immediately after birth is sterile and susceptible to colonization by various microorganisms, including also the pathogenic ones of the coli group, or of the genus Salmonella. Probiotic strains compete with pathogenic microorganisms for adhesion and colonization of biological membranes (Nousiainen et al., 2004). While adhering, probiotic bacteria form thin durable layers known as biofilm. Biofilm is composed of bacteria only in a small part. The remainder comprises exopolymers of these bacteria that form the so-called matrix. These include polysaccharides, proteins, nucleic acids and phospholipids. The release of these compounds is the result of adaptation to the environment. Exopolymers affect the biological, physical and chemical characteristics of the biological membrane and form its essential element. Polysaccharide exopolymers maintain the biofilm in the shape of a whole, as they fill the gaps formed among microorganisms. Usually biofilm contains 4 times more polysaccharide exopolymers than proteins. In the early stages of biofilm formation these are the polisaccharides that are released with the greatest intensity. They help the first cells to attach to the surface. Other exopolymers secreted by cells are proteins. Initially, proteins are gathered on the surface of the cells, and later, when they are released, they associate on the target surface, which helps to keep the cells on the surface. Proteins are usually a mixture of collagen and elastin. They form the extracellural matrix to which microorganisms adhere (Czaczyk, 2003).

In the control of intestinal microflora an important role is played by metabolites of lactic acid bacteria with antagonistic activity. Among the compounds that inhibit the growth of pathogenic microorganisms, the ones considered to be the most important are organic acids, especially lactic acid and acetic acid, as well as hydrogen peroxide and bacteriocins (Salminen et al., 1998; Saarela et al., 2000; Mercenier et al., 2003). Antibacterial effect of organic acids is due to a rapid reduction in $\mathrm{pH}$ values beyond the optimum value range for the growth of most microorganisms, i.e. 6-7, as well as the inhibition of biochemical activity of microorganisms by undissociated acid molecules (Boris \& Barbés, 2000; Messens \& de Vuyst, 2002). Weak acids (lactic and acetic acid) as lipophilic compounds in the undissociated form pass into the cytoplasm, where they dissociate, which results in the reduction of $\mathrm{pH}$ inside the cell and the disruption of the process of moving protons through 
the outer membrane and the increase in its tension. This in turn is manifested by an increase in the permeability. They can also cause denaturation of proteins (Ekuland, 1989; Caplice \& Fitzgerald, 1999). The effect of lactic acid on the permeability of the outer membrane of Escherichia coli, Pseudomonas aeruginosa, Salmonella Typhimurium was examined by Alakomi et al., (2000). These researchers observed that even $5 \mathrm{mM}$ of lactic acid ( $\mathrm{pH} 4.0)$ resulted in a significant increase in the permeability of the outer membrane in case of each of the strains studied by them, and the effect of lactic acid was even stronger than the effect of EDTA or $\mathrm{HCl}$. The dissociation constant of lactic acid is 3.08, and in case of acetic acid it equals 4.87 . Acetic acid, due to higher $\mathrm{pKa}$, shows stronger antimicrobial activity than lactic acid (Cherrington et al., 1991). According to Eklund (1983), the reduction of $\mathrm{pH}$ of the environment to 4.0 leads to the situation where the undissociated form of acetic acid equals $85 \%$, and in case of lactic acid it constitutes only $11 \%$. Acetic acid is a potent inhibitor of the growth of bacteria, yeasts and molds (Blom \& Mörtvedt, 1991). Ray (1992), showed that in an environment with $\mathrm{pH}$ of 5.0 in $1 \%$ solution of acetic acid there are enough undissociated molecules to inhibit the growth of Gram-positive and Gram-negative bacteria, while in $1 \%$ solution of lactic acid the number of undissociated molecules is enough only to inhibit Gram-negative bacteria. Thus, during the fermentation with facultative heterofermentative strains of $\mathrm{LAB}$, lactic acid is mainly responsible for lowering $\mathrm{pH}$ of the environment, while the acetic acid acts as an antimicrobial factor (Ouwehand \& Vesterlund, 2004). It should be noted, however, that lactic acid not only lowers $\mathrm{pH}$, but also functions as a factor causing increased permeability of the outer membrane of Gram-negative bacteria, and thus it may increase the effectiveness of other antagonistic substances (Alakomi et al., 2000).

Lactobacillus, and some other lactic acid-producing bacteria, in the absence of heme, do not use the cytochrome system (which reduces oxygen to water) for the final oxidation. These bacteria use flavoproteins that convert oxygen into hydrogen peroxide. The production of hydrogen peroxide is catalyzed by different enzyme systems present in the cells of lactic acid bacteria, namely the pyruvate oxidase, L-lactate oxidase, superoxide dismutase, Dlactate dehydrogenase and $\mathrm{NADH}$ oxidase. Hydrogen peroxide is a well-known antibacterial substance. The activity of $\mathrm{H}_{2} \mathrm{O}_{2}$ results from strong oxidizing properties. Hydrogen peroxide may inhibit the growth or kill other microbes that do not possess or have low levels of enzymes degrading $\mathrm{H}_{2} \mathrm{O}_{2}$, such as catalase and peroxidase. Studies conducted in vitro confirm the inhibition of different bacteria such as: Staphylococcus aureus, Salmonella Typhimurium, Escherichia coli, Clostridium perfringens, Clostridium butyricum and Pseudomonas sp. by hydrogen peroxide (Dembele et al., 1998; Tomas et al., 2004). Bacteriocins are protein substances produced by numerous strains of lactic acid bacteria and propionic acid bacteria. They make a highly diversified group of compounds in terms of physical and biochemical properties. Bakteriocins have a bactericidal or bacteriostatic effect. They attack the cell membranes of microorganisms possessing receptors capable of bonding to them. These receptors are used for the translocation of bacteriocins and other compounds across the cytoplasmatic membrane. Their construction and properties are not fully known yet. Bacteriocins may cause: poration of bacterial cytoplasmatic membrane, which leads to the dispersal of the transmembrane potential and induces leakage of $\mathrm{K}^{+}$ions, ATP and amino acids from the cytoplasm of affected cells; cell lysis; and they may also interfere with or inhibit the synthesis of DNA, RNA and proteins (acting as DNA-zy lub RNA-zy) (Daeschel, 1989; Klaenhammer, 1993; Grajek \& Sip, 2004). Bacteriocynogenic microbes are resistant to the effect of bacteriocins produced by them. Some bacteriocins of lactic acid bacteria are active against pathogens in food, such as, for example Listeria monocytogenes, others inhibit the growth of Gram-positive aerobic and anaerobic bacteria of the genera 
Bacillus and Clostridium (Schillinger \& Holzapfel, 1996). Yeasts of the genus Saccharomyces are characterized by a high content of glucan and mannan in the cell wall and, therefore, may show an affinity to specific bacterial adhesins. Mannans have a high affinity to fimbrial structures (lectins) specific for mannose binding type 1 in pathogenic bacteria, such as Escherichia coli or Salmonella sp. They place themselves in the "hook", i.e. in the area where those undesirable microorganisms adhere to the receptors of epithelial structures of the digestive system. Then, pathogenic bacteria lose the ability to adhere to the epithelial surface and thus, given the structure of the mannan which is not digested by the endoenzymatic system of animals, they are passaged (transported) along the axis of the intestinal tract and excreted with the feces of birds. Studies have demonstrated adherence of E. coli to the cells of Saccharomyces cerevisiae var. boulardii, and agglutination was similar to that observed between E. coli and erythrocytes, phagocytes and epithelial cells (Gedek, 1999). As demonstrated by the in vitro and in vivo research, yeasts exert inhibitory effects on Salmonella Typhi, Salmonella Typhimurium, Staphylococcus aureus, Pseudomonas aeruginosa, Shigella atypical, Escherichia coli, Clostridium difficile, Klebsiella sp., Yersinia enterocolitica, Candida albicans, Candida pulcherrima, Candida kruzei, Candida pseudotropicalis, Torulopsis gropengiesseri (Tasteyre et al., 2002; Van der Aa Kühle et al., 2005).

At the current stage of research, it seems that the beneficial properties of various probiotics used in animal nutrition are strain-dependent. Hence, attention is paid so that they are strictly defined. Each requires a separate set of tests in order to determine their probiotic properties (FAO/WHO, 2002).

The aim of our research was to design and evaluate the effectiveness of a probiotic preparation intended for poultry. The basis of this preparation are bacteria of the genus Lactobacillus: Lactobacillus paracasei ŁOCK 0920, Lactobacillus brevis ŁOCK 0944, Lactobacillus plantarum ŁOCK 0945 (Michałowski et al., 2004). Strains were characterized for their probiotic properties (Motyl, 2002; Motyl \& Klewicka unpublished data, 2003). The study determined, among others, the resistance of the tested strains to low $\mathrm{pH}$, the ability to adhere to intestinal epithelial cells and the antagonistic activity of these strains in relation to pathogenic strains that cause food poisonings and disease states in animals.

All tested cultures of Lactobacillus sp. showed a strong activity in respect of inhibiting the growth of both Gram-negative pathogenic strains (Pseudomonas aeruginosa, Escherichia coli, Salmonella Typhimurium, Salmonella Enteritidis, Shigella sonnei) and Gram-positive pathogenic strains (Staphylococcus aureus, Enterococcus faecalis, Listeria monocytogenes, Listeria innocua). It is worth noting that Pseudomonas aeruginosa bacteria were inhibited in the strongest way, and Enterococcus faecalis bacteria were inhibited with the weakest effectiveness (Table 1).

Due to the different sensitivity of various pathogenic bacteria to the metabolites of probiotic strains, it seems reasonable to use in animal feeding probiotic preparations made as a composition of different strains, which is consistent with literature data (Mountzouris et al., 2007).

\subsection{Detoxification of mycotoxins}

Mycotoxins are toxic secondary metabolites of fungi mainly belonging to the genera Aspergillus sp., Penicillium sp. and Fusarium sp. Chemically, they are enumerated among aromatic hydrocarbons (sometimes among aliphatic ones) with low molecular weight, which determines their resistance to environmental factors and the absence of or weak immunogenic properties (Gajęcki, 2002). The most important among the mycotoxins, from 


\begin{tabular}{|l|c|c|c|}
\hline \multirow{2}{*}{ The pathogenic strain } & \begin{tabular}{c}
$|c|$ \\
\cline { 2 - 4 }
\end{tabular} & \multicolumn{3}{|c|}{ The antagonistic strain } \\
\cline { 2 - 4 } & \multicolumn{3}{|c|}{ Inhibitor zone (mm) } \\
\hline $\begin{array}{l}\text { Pseudomonas aeruginosa } \\
\text { ATCC 27853 }\end{array}$ & 18.0 & 9.0 & 19.5 \\
\hline $\begin{array}{l}\text { Staphylococcus aureus } \\
\text { ATCC 25923 }\end{array}$ & 14.0 & 9.5 & 12.5 \\
\hline $\begin{array}{l}\text { Escherichia coli } \\
\text { ATCC 25922 }\end{array}$ & 13.5 & 11.5 & 25.5 \\
\hline $\begin{array}{l}\text { Escherichia coli } \\
\text { ŁOCK 0836 }\end{array}$ & 12.0 & 9.0 & 21.5 \\
\hline Escherichia coli 018 & 13.0 & 11.0 & 21.0 \\
\hline Salmonella Enteritidis & 14.0 & 9.0 & 8.0 \\
\hline Salmonella Typhimurium & 9.0 & 10.0 & 7.0 \\
\hline Shigella sonnei & 9.0 & 7.0 & 7.0 \\
\hline Listeria monocytogenes & 12.0 & 14.0 & 12.5 \\
\hline Listeria innocua & 11.0 & 12.0 & 7.0 \\
\hline Enterococcus faecalis & 8.0 & 9.0 & $\begin{array}{c}\text { Lactobacillus plantarum } \\
\text { ŁoCK 0945 }\end{array}$ \\
\hline
\end{tabular}

Table 1. Antagonistic activity of Lactobacillus in relation to microbial food-borne pathogens expressed as a zone of growth inhibition in mm (according to Motyl, 2002; Motyl \& Klewicka unpublished data, 2003).

the toxicological point of view and also taking into account the etiology of some animal diseases are: aflatoxins $\left(\mathrm{AFB}_{1}, \mathrm{AFB}_{2}, \mathrm{AFG}_{1}, \mathrm{AFG}_{2}\right)$, ochratoxins (OTA and OTB), trichothecenes (DON, NIV, T-2, HT-2, DAS), zearalenone (F-2) and fumonisins $\left(\mathrm{FB}_{1}, \mathrm{FB}_{2}\right.$, $\mathrm{FB}_{3}$ ). The synthesis of mycotoxins by fungi is genetically conditioned, but it is determined by environmental factors, which include: substrate composition, its texture, moisture, temperature and the presence of competitive microflora (Gourama \& Bullerman, 1995; Batish et al., 1997; Fink-Gremmels, 1999). The invasion of mycotoxins into the body of animals takes place mainly via food, and the health effects, called mycotoxicoses, are poisonings with various courses - acute or chronic - resulting from the receiving small doses for a long time (Yiannikouris \& Jouany, 2002). Due to the specific chemical and physical properties of mycotoxins, the spectrum of their activities in the body of animals is very different and it is characteristic for the groups of these metabolites. First of all, mycotoxins have a specific effect on the groups of body tissues (epithelia, nervous system tissue, secretory organs tissue - the pancreas, liver, kidney tissue, etc.), including the individual cells. By interfering with metabolic pathways, they may lead to abnormal replication of the cell's genetic code, which impairs the process of tissue proteins reconstruction (including the immune system - proteins of antibodies). They also damage and disrupt transport mechanisms in the cytoplasm of cells and between cells, block enzymatic reactions of cells, especially in mitochondria, as well as within cells. In addition, they may block co-factors of metabolic reactions, such as some vitamins. A significant adverse influence of numerous mycotoxins has also been confirmed (in particular of OTA, AFB $1, \mathrm{DON}$ and T-2) on the antioxidant components of cells and tissues, indicating at the same time this process as on 
the most dangerous for the organism's equilibrium and the occurrence of immunosuppression and oxidative stress (Sharma, 1993; Benett \& Klich, 2003).

According to the current knowledge (Huwing et al., 2001; Diaz et al., 2004), removal of toxins from grains and feed can be carried out by mechanical separation of contaminated grains (sorting), addition of adsorptive materials, and using the activity of physical, chemical and biological factors.

Among the many microbes that show the potential for detoxification, special interest is aroused by lactic acid bacteria and yeasts (Shetty \& Jespersen, 2006). Initial studies have shown that different strains of lactic acid bacteria can inhibit the biosynthesis of aflatoxins (Coallier-Ascah \& Idziak, 1985). The concept of using yeasts to remove mycotoxins during fermentation processes appeared in the studies conducted by Benneta et al. (1981), who used corn contaminated by zearalenone as a substrate for alcohol production with the participation of yeasts of the genus Saccharomyces.

Literature data shows that apart from common lactic bacteria there appear varieties with different abilities to detoxify the environments from mycotoxins (Oatley, 2000). The research of EL-Nezami et al. (1996, 1998, 2000 a and b) proves that these properties are manifested by strains of Lactobacillus rhamnosus (LBGG and LC705). Styriak et al. (2001), examined the ability of 10 yeast strains of the genus Saccharomyces, Kluyveromyces and Rhodotorula to detoxify fumonisin $B_{1}$, toxin T-2 and ochratoxin A. Out of the tested organisms, yeasts of the genus Saccharomyces were characterized with the greatest predispositions in the area in question.

The research on the abilities of probiotic preparations for poultry manifested in the area of biological detoxification of mycotoxins, carried out under in vitro conditions (Biernasiak et al., 2006), showed that after six hours of incubation, the loss of aflatoxins in the control sample of feed, where there was no process of fermentation, equaled from 28 to $30 \%$, and in case of ochratixin A it equaled from 8 to $10 \%$. After twenty-four hours of incubation of the control sample with the addition of $[5 \mu \mathrm{g} / \mathrm{kg}]$ ochratoxin A, a further loss was noted which equaled $10 \%$, and $2 \%$ for the medium with the addition of [50 $\mu \mathrm{g} / \mathrm{kg}$ ]. The concentration of aflatoxins increased from 5 to $10 \%$, probably as a result of desorption (Figure 2).

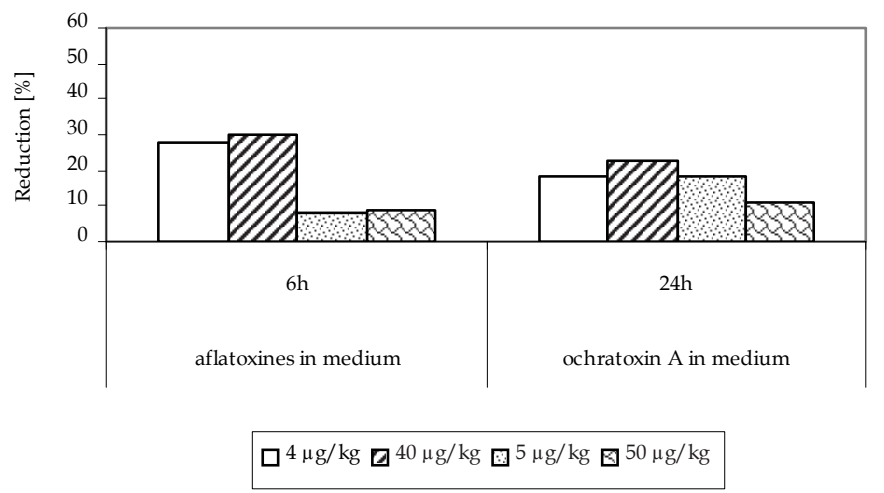

Fig. 2. Reduction of aflatoxins and ochratoxin A concentration in the sample without fermentation 
After six hours of fermentation with the addition of probiotic cultures, the quantity of aflatoxins was reduced by 18 to $33 \%$ compared to that recorded in the control sample, and as for ochratoxin A the reduction equaled from 29 to $49 \%$. After the fermentation, the loss of ochratoxin A, both at a low concentration, namely $5 \mu \mathrm{g} / \mathrm{kg}$, and at a high concentration, namely $50 \mu \mathrm{g} / \mathrm{kg}$, was at a similar level and equaled $50 \%$. The same relationship was also noted for low levels of aflatoxins, i.e. for $4 \mu \mathrm{g} / \mathrm{kg}$ inserted into the fermentation medium. At high concentration, i.e. $40 \mu \mathrm{g} / \mathrm{kg}$, the loss of aflatoxins was lower and amounted to about $30 \%$ (Figure 3).

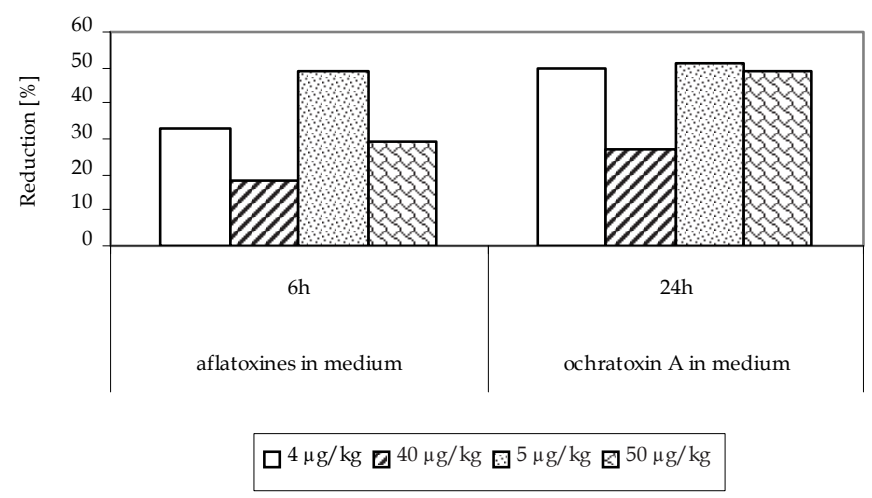

Fig. 3. Reduction of aflatoxins and ochratoxin A concentration during fermentation with the use of probiotic bacteria and yeasts

During a spontaneous fermentation, the loss of mycotoxins was much lower, and after six hours of fermentation a decrease was observed by $6-8 \%$ in the concentration of aflatoxins in relation to the initial concentration recorded in the control sample, and for ochratoxin A the decrease equaled to from 12 to $19 \%$. After the fermentation, the loss of both aflatoxins and ochratoxin A was at a similar level from 16-24\% compared with the medium in which no fermentation occurred (Figure 4). It was found that the probiotic vaccine creates a probiotic starter culture endowed with a stable feature of detoxification of mycotoxins, and particularly ochratoxin A.

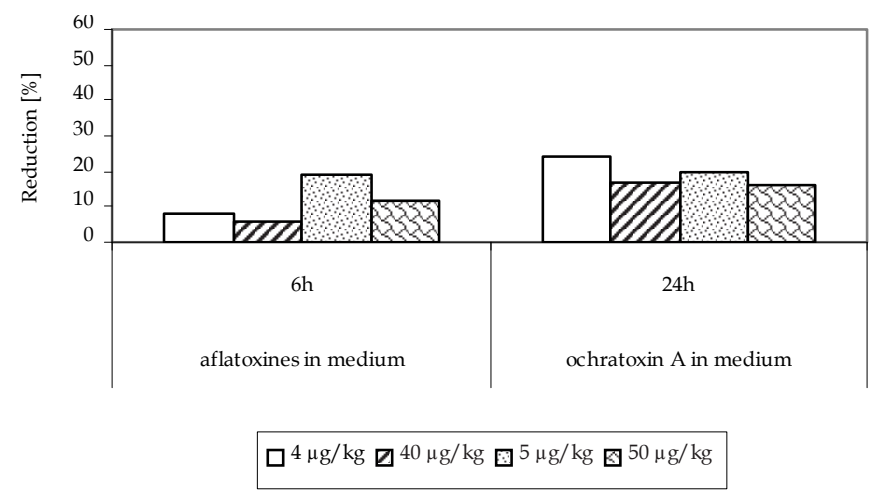

Fig. 4. Reduction of aflatoxins and ochratoxin A concentration during spontaneous fermentation 
Śliżewska (unpublished data) examined the ability of a probiotic preparation to counteract the deleterious effects of aflatoxin $\mathrm{B}_{1}\left(\mathrm{AFB}_{1}\right)$ in broiler chickens (in vivo experiments). The probiotic preparation used contained (per $1 \mathrm{~kg}$ ): $10^{10}$ of Lactobacillus cells (L. paracasei LOCK 0920, L. brevis LOCK 0944 and L. plantarum LOCK 0945), $10^{6}$ of yeast Saccharomyces cerevisiae LOCK 0140 cells and 50g of Yucca schidigera extract. The Ross broiler chicks from a commercial hatchery were used in this study. The chickens were divided into four experimental groups depending on the feed administered to them: fed with the feed contaminated with 1 or $5 \mathrm{mg}$ of $\mathrm{AFB}_{1}$ per $\mathrm{kg}$, and fed with the feed contaminated with $\mathrm{AFB}_{1}$ and supplemented with the probiotic preparation. The amount of aflatoxin $B_{1}$ in the feces was determined for each week of rearing in 10 chickens in each group. After 35 days (of rearing) chickens were slaughtered and the concentration of toxins in the liver and kidneys was determined. The histopathological changes were evaluated in tissue sections obtained from the liver and kidneys of the tested animals.

The research showed that the presence of probiotics in the feed resulted in a statistically significant increase in the quantity of aflatoxin $B_{1}$ excreted in the feces of the chickens. At the end of breeding, i.e. on the $35^{\text {th }}$ day, in the feces of chickens consuming feed contaminated with aflatoxin $B_{1}$ (at a concentration of 1 or $5 \mathrm{mg} / \mathrm{kg}$ ) and containing the probiotic preparation, the content of toxins was higher by $67 \%$ and $31 \%$ compared to the feces of chickens consuming feed without the probiotic. The addition of the probiotic preparation prevented the accumulation of toxins in the organs (liver and kidneys) in the extent observed in the case of chickens consuming feed without the probiotic (Table 2). The toxins were not accumulated in the organs in such large amounts as in the case of chickens consuming feed without probiotics, and they were excreted to a greater extent in the feces.

\begin{tabular}{|c|c|c|c|c|c|}
\hline \multicolumn{6}{|c|}{ Test group } \\
\hline & & $\begin{array}{c}1 \mathrm{mg} / \mathrm{kg} \\
\mathrm{AFB}_{1}\end{array}$ & $\begin{array}{c}\text { 1mg/kg AFB } \\
\text { +probiotic }\end{array}$ & $\begin{array}{c}5 \mathrm{mg} / \mathrm{kg} \\
\mathrm{AFB}_{1}\end{array}$ & $\begin{array}{c}5 \mathrm{mg} / \mathrm{kg} \mathrm{AFB} \\
\text { +probiotic }\end{array}$ \\
\hline \multicolumn{6}{|c|}{ Concentration of aflatoxin $B_{1}[\mu \mathrm{g} / \mathrm{kg}]$} \\
\hline \multirow{2}{*}{ Feces } & Range & $0.21-0.47$ & $0.52-1.25$ & $2.52-2.88$ & $3.68-7.50$ \\
\hline & Mean* & $0.29( \pm 0.10)^{\mathrm{a}}$ & $0.89( \pm 0.30)^{\mathrm{b}}$ & $2.74( \pm 0.13)^{\mathrm{c}}$ & $4.00( \pm 1.61)^{\mathrm{d}}$ \\
\hline \multirow{2}{*}{ Liver } & Range & $8.30-9.64$ & $2.10-4.52$ & $8.42-14.84$ & $3.52-7.20$ \\
\hline & Mean* & $8.86( \pm 0.49)^{\mathrm{a}}$ & $3.69( \pm 0.95)^{b}$ & $11.84( \pm 2.99)^{\mathrm{c}}$ & $5.88( \pm 1.69)^{\mathrm{d}}$ \\
\hline \multirow{2}{*}{ Kidneys } & Range & $4.60-11.62$ & $1.24-3.60$ & $10.10-17.16$ & $2.94-4.62$ \\
\hline & Mean* & $7.93( \pm 2.91)^{\mathrm{a}}$ & $2.55( \pm 0.96)^{\mathrm{b}}$ & $13.71( \pm 2.76)^{\mathrm{c}}$ & $4.06( \pm 0.68)^{\mathrm{d}}$ \\
\hline
\end{tabular}

* Results are presented as an arithmetic mean ( \pm standard deviation)

ab Values in rows denoted with different letters differ considerably for $\mathrm{P}<0.05$

Table 2. Concentration of aflatoxin $B_{1}$ in the feces, liver and kidneys

Pathological changes were observed in the livers of chickens consuming the feed contaminated with aflatoxin $B_{1}$ at both concentrations ( 1 and $5 \mathrm{mg} / \mathrm{kg}$ of feed). The changes were similar in type (fibrosis of the portal area and liver parenchyma, eosinophil infiltrates in the portal area, steatosis of hepatocytes), but the changes in the livers of chickens consuming the feed contaminated with aflatoxin $\mathrm{B}_{1}$ and supplemented with probiotics were slightly less severe. The strongest toxic changes were found in the group of chickens consuming the feed contaminated with aflatoxin $B_{1}$ at $5 \mathrm{mg} / \mathrm{kg}$ of feed (Figure 5). These 
changes revealed the characteristics of micronodular cirrhosis with very severe eosinophil infiltrates.

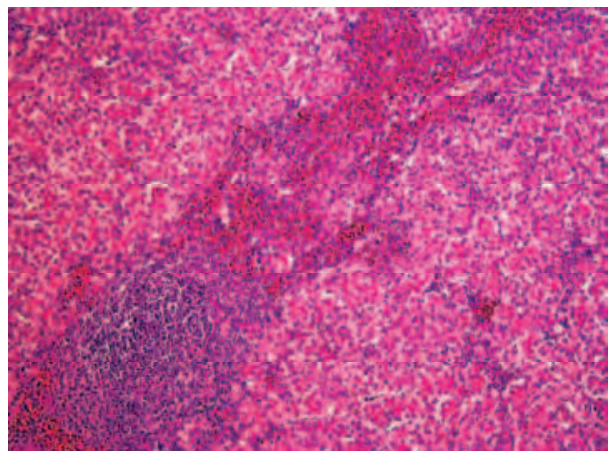

(a)

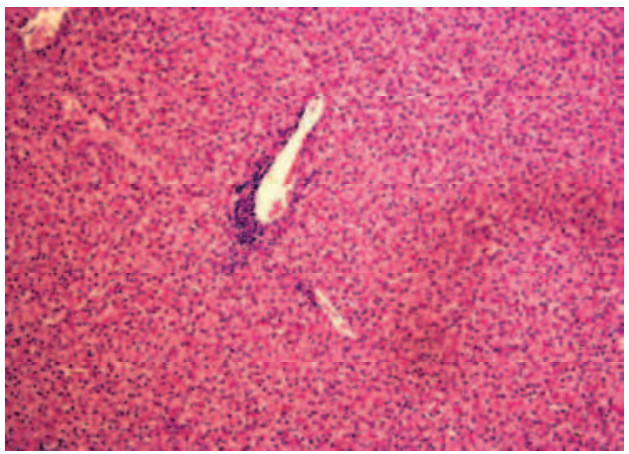

(b)

(a) Eosinophil infiltrates and enlarged lymphatic node (b) Eosinophil infiltrates

Fig. 5. Histological changes in the liver of chickens fed with the feed contaminated with $\mathrm{AFB}_{1}(\mathrm{a})$ and supplemented with a probiotic preparation (b).

Kidney damage was found only in the chickens consuming the feed contaminated with 5 $\mathrm{mg} / \mathrm{kg}$ of aflatoxin $\mathrm{B}_{1}$; however, in the chickens consuming the feed with probiotics, the intensity of the changes was smaller. The changes concerned enlargement of renal glomeruli and an increase of mezangium matrix and cells (Figure 6).

While supplementation of feed with the probiotic preparation does not constitute protection against pathological changes in organs, it reduces the changes primarily in the kidneys.

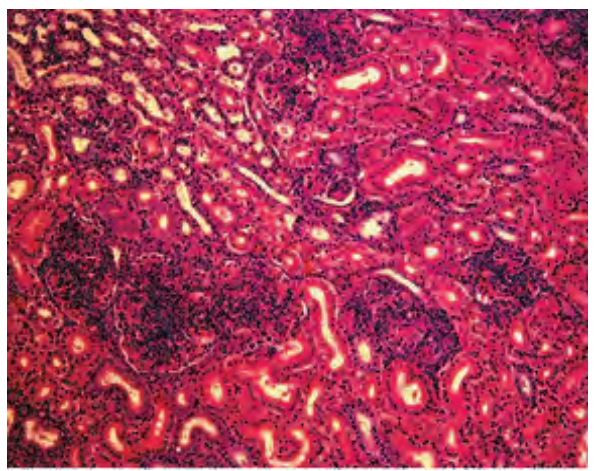

(a)

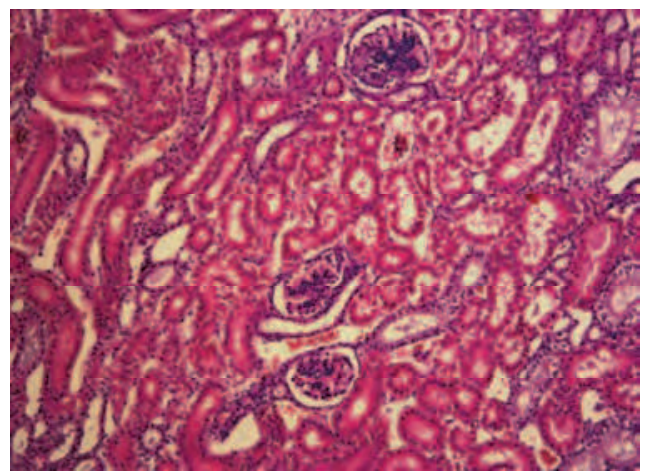

(b)

(a) Gromeruli diameter - 200-400 $\mu \mathrm{m}$ (b) Gromeruli diameter - 150-200 $\mu \mathrm{m}$

Fig. 6. Histological changes in kidneys of the chickens fed with the feed contaminated with $\mathrm{AFB}_{1}(\mathrm{a})$ and supplemented with probiotic preparation (b).

\subsection{The immunological system stimulation}

The microbes of intestinal microflora are the main factor stimulating the immune system, which is a prerequisite for the development of lymphoid structures of the system 
(laboratory animals born and kept in sterile conditions do not develop them). Immunomodulating effect of intestinal microflora, including that of probiotic bacteria is based on three seemingly contradictory phenomena (Dugas et al., 1999; Isolauri et al., 2001):

- induction and maintenance of immune tolerance to environmental antigens (food and inhalants)

- induction and control of immune responses against pathogens of bacterial and viral origin

- inhibition of autoimmune and allergic reactions.

For example, in the case of chickens, GALT (gut-associated lymphoid tissue) reaches full maturity after two weeks since hatching (Bar-Shira et al., 2003). Until then, in the gastrointestinal immune system there are T and B cells, macrophages and NK cells (Lillehoj \& Trout, 1996). The aim of the research conducted by Haghighi et al. (2006), was to determine the effect of probiotic bacteria on the increase of natural antibodies (IgA, IgG and IgM) in the intestinal content and blood serum of chickens. The chickens were divided into two groups. Group I was administered to the beak $0.5 \mathrm{ml}$ of PBS buffer containing $10^{6}$ of bacteria, namely Lactobacillus acidophilus, Bifidobacterium bifidum and Enterococcus faecalis, while Group II received 0.5 of PBS buffer without additives (control group). It was demonstrated that the intestinal content of the chickens receiving the probiotic, compared with the control group, had increased level of IgA antibodies $(\mathrm{P}<0.001)$, reactive against the tetanus toxin (TT), alpha-toxin of Clostridium perfringns and bovine serum albumin (BSA). Similar relationships were recorded in relation to IgG antibodies, but they were reactive only to TT. The serum of the chickens treated with the probiotic showed an increased level of IgG antibodies $(\mathrm{P} \leq 0.05)$, but they were reactive only to TT and alfa-toxin. Similar dependencies $(\mathrm{P} \leq 0.01)$ were noted for IgM antibodies.

\section{Effects of the application of probiotics in animal nutrition}

The earliest from of probiotics, still widely used in animal nutrition, was based on silage, whose usefulness has been proven by many years of use. Modern probiotic preparations must be subjected to comprehensive testing in accordance with Commission Directive 94/40/EC of 22 July 1994 setting out procedures for the assessment of additives in animal nutrition.

The usefulness of probiotics in the nutrition of young pigs has been shown, although the results varied greatly from one another especially in relation to such indicators of production as growth and feed efficiency (Turner et al., 2002). The outcome of most studies indicate the beneficial effect of probiotics on the health of piglets. The most frequently observed effect is a reduction in the incidence rate of diarrhea and shortening of its duration, as well as a decrease in the mortality rate of piglets during the pre-weaning and peri-weaning period (Ross et al., 2008 \& 2010). It was demonstrated that the best results are obtained when the probiotic is administered already on the first, or on the second day of life at the latest. That is why probiotics are administered to them after birth orally in the form of a special paste with the use of special dispensers (Janik et al., 2006). Literature reports on the effects of the application of probiotics in case of chickens are mixed, similarly to those referring to pigs.

The study conducted by Smulikowska et al., (2005) demonstrated that feeding broiler chickens with the feed supplemented with a probiotic preparation LABYuc-Probio (containing in 1g: $4.7 \times 10^{7}$ of Lactobacillus bacteria, $2.0 \times 10^{3}$ of Saccharomyces cerevisiae yeasts 
and $50 \mathrm{mg}$ of Yucca schidigera extract) did not result in significant changes in the body weight gains and feed utilization compared with a group of chickens receiving antibiotic feed with or without any additions.

Similar relationships were obtained in studies conducted by Watkins \& Kratzer, (1983 \& 1984) and Maiolino et al., (1992). However, in a group of chickens receiving a mixture supplemented with a probiotic preparation, the body mass of birds in different periods of rearing was the most uniform, as evidenced by lower standard deviation (SD). It was found that, regardless of the use of a probiotic feed additive, an antibiotic, or the total lack of supplements, the relative weights of liver, pancreas, abdominal fat and the individual sections of the gastrointestinal tract converted to \% of the chickens' body weights before slaughter were similar and statistically insignificant. The research by Jin et al. (1998), showed that addition to the chickens' diet of L. acidophilus or a mix of bacteria of the genus Lactobacillus, namely L. acidophilus (2), L. fermentum (3), L. crispatus (1) and L. brevis (6), had no statistically significant effect either on the weight of the crop, liver, spleen, duodenum and small intestine expressed as \% of the body weight of chickens prior to slaughter. Similar dependencies were also obtained in the studies of Fethiere \& Miles, (1987) and Watkins \& Kratzer, (1984).

In addition, our own study (Biernasiak et al., 2009) showed that supplementing feed with a probiotic preparation LABYuc-Probio ${ }^{\circledR}$ already during the first week of rearing resulted in a significant reduction in the number of bacteria of the genus Clostridium in the fecal-urate excreta of chickens. The number of these bacteria was about $10^{5} \mathrm{CFU} / \mathrm{g}$, while in the fecalurate excreta of broiler chickens fed with the feed supplemented with an antibiotic or the feed without any additives it was higher by about two orders of magnitude. After the second week of rearing, regardless of the type of feed supplementation, there was noted a decrease by one order of magnitude in the number of bacteria of the genus Clostridium. After the third week of rearing, the further reduction in the number of bacteria of the genus Clostridium was observed, but only in the fecal-urate excreta of broiler chickens feed with the feed supplemented with the probiotic preparation. The number of bacteria then equaled around $10^{3} \mathrm{CFU} / \mathrm{g}$ and it was lower by three orders of magnitude compared to that recorded in the fecal-urate excreta of the chickens included into the two remaining groups. After the fourth week of rearing, depending on the type of feed supplementation, a differentiation of the number of bacteria was observed; from $10^{4} \mathrm{CFU} / \mathrm{g}$ to $10^{5} \mathrm{CFU} / \mathrm{g}$. Nevertheless, it must be emphasized that still the lowest number $\left(10^{4} \mathrm{CFU} / \mathrm{g}\right)$ of the studied microorganisms was recorded in the fecal-urate excreta of birds fed with the feed supplemented with the probiotic preparation. After the fifth and sixth week of rearing, the number of bacteria of the genus Clostridium in the fecal-urate excreta of broilers fed with the feed with the probiotic or without additional supplements was at the same level and amounted to approximately $10^{5} \mathrm{CFU} / \mathrm{g}$. The birds receiving the feed with antibiotics, compared with the other two, still manifested a higher number of these bacteria, by respectively, two orders of magnitude, and one order of magnitude (Figure 7). Analysis of variance Anova showed statistically significant differences between the kind of feed supplementation, and the number of bacteria of the genus Clostridium in the fecal-urate excreta of chickens in the period from the second to the fifth week of rearing $(0.01<p<0.05)$. The obtained results are particularly important in view if the fact that after the withdrawal of antibiotic growth promoters from poultry feed mixtures an increase may be expected in the incidence of intestinal problems, especially related to Clostridium perfringens, i.e. necrotic 
enteritis (NE). In France, the occurrence of NE increased from 4.0\% in 1995 to $12.4 \%$ in 1999 and similar dependencies were also observed in other European countries (Lipiński, 2007).

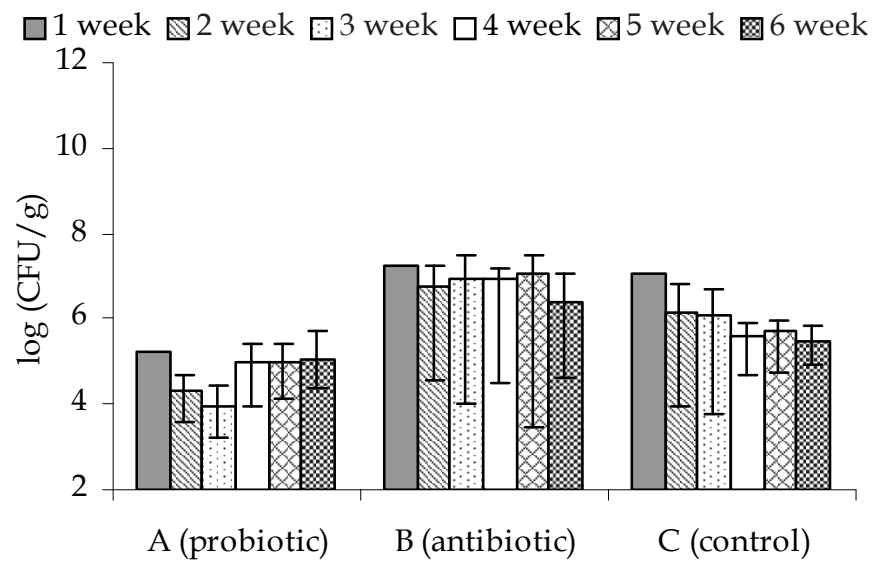

Fig. 7. Bacteria of the genus Clostridium in the feces of chickens

Supplementing the feed with the probiotic preparation LABYuc-Probio ${ }^{\circledR}$ also contributed to the stabilization of the number of Enterobacteriaceae, including bacteria from the coli group in the chickens' fecal-urate excreta during individual weeks of rearing (Figure 8).

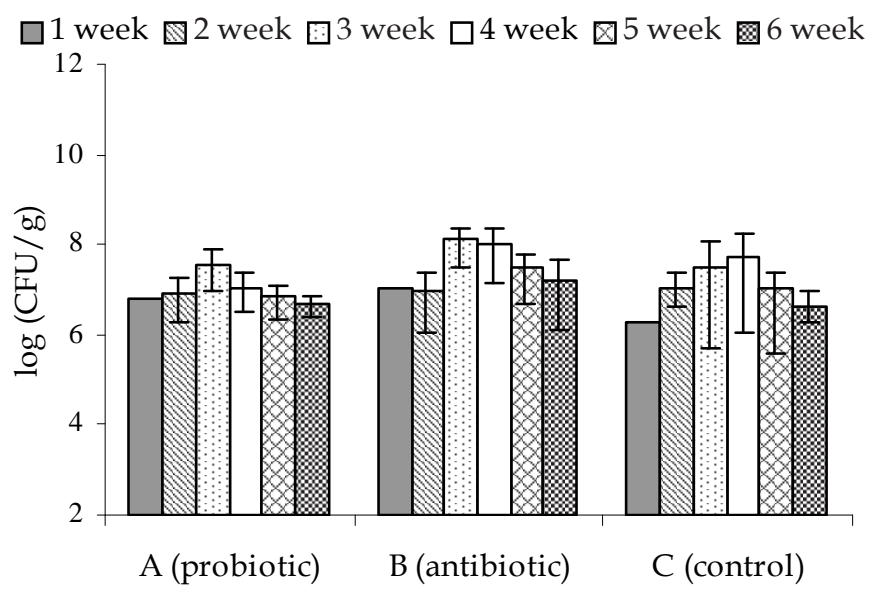

Fig. 8. Total number of bacteria of the coli group in the feces of chickens

Kralik et al. (2004) recorded a decrease in the number of Enterobacteriaceae and bacteria of the coli group by about $90 \%$, compared to the control group, i.e. $1.39 \times 10^{6}$ and $2.72 \times 10^{5} \mathrm{CFU} / \mathrm{g}$ after 42 days of supplementing water with a probiotic containing $5 \times 10^{9} \mathrm{CFU} / \mathrm{g}$ of Enterococcus faecium M-74. However, he did not find statistically significant differences in the 
number of bacteria of the genera Staphylococcus sp., Bacillus sp. and Clostridium sp. Jin et al., (1998) showed that the addition of L. acidophilus or a mixture of bacteria of the genus Lactobacillus into the chickens' diet had a statistically significant effect $(\mathrm{P}<0.05)$ on the decrease in the number of bacteria of the coli group in the blind gut, compared to the control sample, but only on the $10^{\text {th }}$ and $20^{\text {th }}$ day of rearing. At the same time, he registered no similar changes in the small intestine.

An average number of bacteria of the genus Lactobacillus in the fecal-urate excreta of all studied groups of chickens during individual weeks of rearing equaled from $10^{9}$ to $10^{10}$ $\mathrm{CFU} / \mathrm{g}$ (Figure 9). Data analysis showed that only after the third week of rearing there were recorded statistically significant differences $(p<0.01)$ between the type of feed additive, and the number of bacteria of the genus Lactobacillus found in the birds' fecal-urate excreta (Biernasiak \& Slizewska, 2009). The research of Jin et al., (1998) demonstrated that supplementation with L. acidophilus or a mixture of bacteria of the genus Lactobacillus did not have an influence on the statistically significant increase in the number of bacteria of the genus Lactobacillus in the blind gut during the individual weeks of rearing, and in case of the small intestine significant changes were recorded only on the 30th day of rearing. Similarly, the research of Watkins \& Kratzer $(1983,1984)$ found no significant increase in the number of bacteria of the genus Lactobacillus sp. in the chickens' intestines.

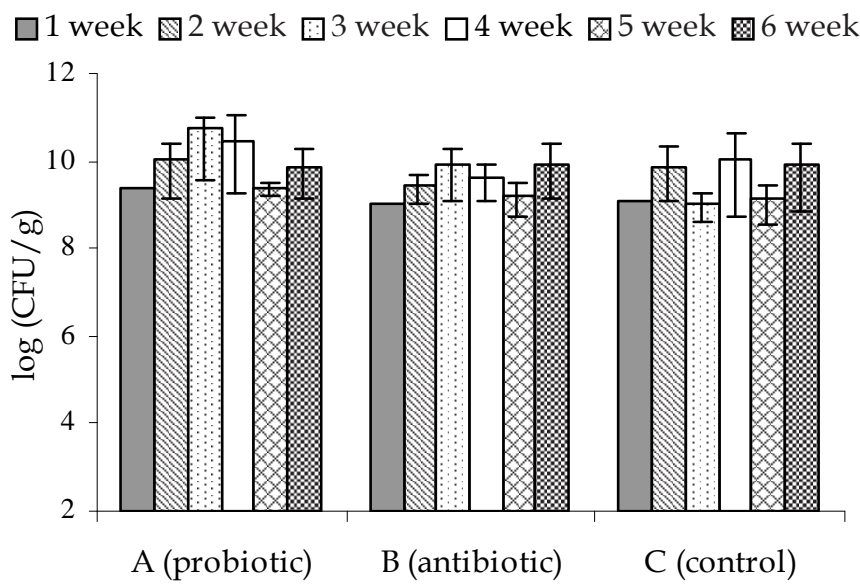

Fig. 9. Bacteria of the genus Lactobacillus in the feces of chickens

While using a probiotic preparation consisting of Bacillus subtillis $\mathrm{CH} 201$ and Bacillus licheniformis $\mathrm{CH} 200$ in the feed for laying hens, a statistically significant decrease was noted $(\mathrm{P}<0.05)$ as for the content of cholesterol and triglycerides in the serum and egg yolk. However, no statistically significant increase in the feed efficiency, egg production, or the impact on the thickness and hardness of the shell was demonstrated (Mahdari et al., 2005). On the other hand, the application of Enterococcus faecium M-74 in the feed for laying hens resulted in obtaining eggs with thicker and more breakage-resistant shells and in a more intense color of the yolk (Angelovicova, 1996).

It should be emphasized that the results presented above represent only a fraction of worldwide research. The divergence of the results in the presented cases indicates the need 
for further research in order to clarify the questionable effects of probiotics in animal nutrition.

The future of probiotics involves aspiring to reach full explanation of mechanisms concerning their activity in relation to mutual microorganism-animal interaction and looking for new bacterial strains, as well. Delimitation of appropriate directions of research can have a great meaning for newly described principles of prophylaxis in animal nutrition without using antibiotic growth stimulators.

\section{References}

Alakomi, H.L.; Skytta, E.; Saarela, M.; Mattila-Sandholm, T.; Latva-Kala, K. \& Helander, I.M. (2000). Lactic acid permeabilizes gram-negative bacteria by disrupting the outer membrane. Applied and Environmental Microbiology, Vol. 66, No. 5, pp. 20012005, ISSN 1098-5336

Anadón, A.; Martinez-Larrañaga, M.R. \& Martinez, M.A. (2006). Probiotics for animal nutrition in the European Union. Regulation and safety assessment. Regulatory. Toxicology and Pharmacology, Vol. 45, pp. 91-95, ISSN 0273-2300

Angelowicova, M. (1996). The effect of Streptococcus faecium M-74 based probiotic on the performance of laying hens. Czech Journal of Animal Science, Vol. 41, No. 9, pp. 391395, ISSN 1212-1819

Bar-Shira, E.; Sklan, D. \& Friedman, A. (2003). Establishment of immune competence in the avian GALT during the immediate post-hatch period. Developmental $\mathcal{E}$ Comparative Immunology, Vol. 27, pp. 147-157, ISSN 0145-305X

Batish, V.K.; Uptal, R.; Ram, L. \& Grover, S. (1997). Antifungal attributes of lactic acid bacteria - a review. Critical Reviews in Biotechnology, Vol. 17, No. 3, pp. 209-225, ISSN 0738-8551

Bennett, G.A.; Lagoda, A.A.; Shotwell, O.L. \& Hesseltine, C.M. (1981). Utilization of zearalenone-contaminated corn for ethanol production. Journal of the American Oil Chemists' Society, Vol. 58, pp. 974-976, ISSN 0003-021X

Bennett, J.W. \& Klich, M. (2003). Mycotoxins. Clinical Microbiology Reviews, Vol. 16, No. 3, pp. 497-516, ISSN 0893-8512

Berghmann, L.R.; Abi-Ghanem, D.; Wagnela, S.D. \& Ricke, S.C. (2005). Antibodies: an alternative for antibiotics? Poultry Science, Vol. 84, No. 4, pp. 660-666, ISSN 00325791

Biernasiak, J. \& Śliżewska K. (2009). The effect of a new probiotic preparation on the performance and faecal microflora of broiler chickens. Veterinarni Medicina, Vol. 54, No. 12, pp. 525-531, ISSN 0375-8427

Biernasiak, J.; Piotrowska, M. \& Libudzisz, Z. (2006). Mycotoxins by probiotic preparation for broiler chickens. Mycotoxin Research, Vol. 22, No. 4, pp. 230-235, ISSN 0178-7888

Blom, H. \& Mörtvedt, C. (1991). Anti-microbial substances produced by food associated microorganisms. Biochemical Society Transactions, Vol. 19, pp. 694-698, ISSN 03005127

Boris, S. \& Barbés, C. (2000). Role played by lactobacilli in controlling the population of vaginal pathogens. Microbes and Infection, Vol. 2, No. 5, pp. 543-546, ISSN 1286-4579

Caplice, E. \& Fitzgerald, G.F. (1999). Food fermentations: role of microorganisms in food production and preservation. International Journal of Food Microbiology, Vol. 50, No. 1-2, pp. 131-149, ISSN 0168-1605 
Casewell, M.; Friis, C. \& Marco, E. (2003). The European ban on growth promoting antibiotics and emerging consequences for human and animal health. Journal of Antimicrobial Chemotherapy, Vol. 52, No. 2, pp. 159-161, ISSN 0305-7453

Cherrington, C.A.; Hinton, M.; Pearson, G.R. \& Chopra, I. (1991). Short-chain organic acids at $\mathrm{pH} 5,0$ kill Escherichia coli and Salmonella spp. without causing membrane perturbation. Journal of Applied Bacteriology, Vol. 70, No. 2, pp. 161-165, ISSN 00218847

Coallier-Ascah, J. \& Idziak, E.S. (1985). Interaction between Streptococcus lactis and Aspergillus flavus on production of aflatoxin. Applied and Environmental Microbiology, Vol. 49, No. 1, pp. 163-167, ISSN 1098-5336

Commission Directive 94/40/EC of 22 July 1994 amending Council Directive 87/153/EEC fixing guidelines for the assessment of additives in animal nutrition.

Council Directive 70/524/EEC of 23 November 1970 concerning additives in feedingstuffs.

Council Directive 90/220/EEC of 23 April 1990 on the deliberate release into the environment of genetically modified organisms

Czaczyk, K. (2003). Tworzenie biofilmów bakteryjnych-istota zjawiska i mechanizmy oddziaływan. Biotechnologia, [The creating biofilms of bacteria - the creature the phenomenon and mechanisms of influences. Biotechnology] Vol. 3, pp. 180-192, ISSN 2080-8682 [in Polish]

Daeschel, M. (1989). Antimicrobial substances from lactic acid bacteria for use as food preservatives. Food Technology, Vol. 1, pp. 164-167, ISSN 0015-6639

Dembele, T.; Obdrzalek, V. \& Votava, M. (1998). Inhibition of bacterial pathogens by lactobacilli. Zentralblatt für Bakteriologie, Vol. 288, No. 3, pp. 395-401, ISSN 0934-8840

Diaz, D.E.; Hagler, W.M.; Blackwelder, J.T.; Eve, J.A.; Hopkins, B.A.; Andersen, K.L.; Jones, F.T. \& Whitlow, L.W. (2004). Aflatoxin binders II: Reduction of aflatoxin M1 in milk by sequestering agents of cows consuming aflatoxin in feed. Mycopathologia, Vol. 157, pp. 233-241, ISSN 0301-486X

Dugas, B.; Mecenier, A.; Lenoir-Wijnkoop, J.; Arnaud, C.; Dugas, N. \& Postaire, E. (1999). Immunity and probiotics. Immunology Today, Vol. 20, No. 9, pp. 387-389, ISSN 01675699

Eklund, T. (1983). The antimicrobial effect of dissociated and undissociated sorbic acid at different $\mathrm{pH}$ levels. Journal of Applied Bacteriology, Vol. 54, pp. 383-389, ISSN 00218847

Ekuland, T. (1989). Organic acids and esters. In: Mechanisms of Action of Food Preservation Procedures, G. W. Gould (Ed.), 161-200, London, ISBN 1851662936, Elsevier Applied Science

El-Nezami, H.; Kankaanp, P.; Salminen, S. \& Ahokas, J. (1998). Ability of dairy strains of lactic acid bacteria to bind a common food carcinogen, aflatoxin $\mathrm{B}_{1}$. Food and Chemical Toxicology, Vol. 36, pp. 321-332, ISSN 0278-6915

El-Nezami, H.S.; Chrevatidis, A.; Auriola, S.; Salminen, S. \& Mykkänen, H. (2002a). Removal of common Fusarium toxins in vitro by strains of Lactobacillus and Propionibacterium. Food Additives and Contaminants, Vol. 19, pp. 680-686, ISSN 0265-203X

El-Nezami, H.S.; Polychronaki, N.; Salminen, S. \& Mykkänen, H. (2002b). Binding rather than metabolism may explain the interaction of two food grade Lactobacillus strains with zearalenone and its derivative $\alpha$-zearalenol. Applied and Environmental Microbiology, Vol. 68, No. 7, pp. 3545-3549, ISSN 1098-5336

El-Nezami, H.S.; Salminen, S. \& Ahokas, J.T. (1996). Biologic control of food carcinogen using Lactobacillus GG. Nutrition Today, Vol. 31, pp. 41-43, ISSN 0029-666X 
FAO (2002) Guidelines for the Evaluation of Probiotics in Food. Report of a Joint FAONWHO Working Group on Drafting Guidelines for the Evaluation of Probiotics in Food, Londyn Ontario, Kanada, April 30 and May 1, 2002 r.

Fethiere, R. \& Miles, R.D. (1987). Intestinal tract weight of chicks fed an antibiotic and probiotic. Nutrition Reproduction Incorporation, Vol. 36, pp. 1305-1309, ISSN 16083369

Fink-Gremmels, J. (1999). Mycotoxins: their impact on human and animal health. Veterinary Quarterly, Vol. 21, pp. 115-120, ISSN 0042-4900

Gajęcki, M. (2002). Mikotoksyny jako czynnik antyżywieniowy w produkcji zwierzęcej. Hodowca Drobiu [Mycotoxin as unnutritional factor in animal production. Poultry farmer's], Vol. 9, pp. 5-17, ISSN 1425-963X [in Polish]

Gedek, B.R. (1999). Adherence of Escherichia coli serogroup O 157 and the Salmonella Typhimurium mutant DT 104 to the surface of Saccharomyces boulardii. Mycoses, Vol. 42, No. 4, pp. 261-264, ISSN 0933-7407

Gourama, H. \& Bullerman, L.B. (1995). Antimycotic and antiaflatoxigenic effect of lactic acid bacteria: a review. Journal of Food Protection, Vol. 57, No. 11, pp. 1275-1280, ISSN 0362-028X

Grajek, W. \& Sip, A. (2004). Biologiczne utrwalanie żywności z wykorzystaniem metabolitów bakterii mlekowych. W: Bakterie fermentacji mlekowej Klasyfikacja, metabolizm, genetyka, wykorzystanie. [Biological fixation food with utilization of lactic acid bacteria metabolites In: Lactic acid bacteria. Classification, metabolism, genetiics, application]. Eds. Z. Libudzisz, P. Walczak, J. Bardowski. Politechnika Łódzka [Technical University of Lodz.], pp. 103-197 [in Polish].

Haghighi, H.R.; Gong, J.; Gyles, C.L.; Hayes, M.A.; Zhou, H.; Sanei, B.; Chambers, J.R. \& Sharif, S. (2006). Probiotics stimulate production of natural antibodies in chickens. Clinical and Vaccine Immunology, Vol. 13, No. 9, pp. 975-980, ISSN 1556-6811

Huwing, A.; Freimund, S.; Kappeli, O. \& Dutler, H. (2001). Mycotoxin detoxication of animal feed by different adsorbents. Toxicology Letters, Vol. 122, pp. 79-188, ISSN 0378-4274

Isolauri, E.; Sütas, Y.; Kankaanpää, P.; Arvilommi, H. \& Salminen, S. (2001). Probiotics: effects on immunity. The American Journal of Clinical Nutrition, Vol. 73, pp. 444S450S, ISSN 0002-9165

Janik, A.; Kaska, M.; Paluch, U.; Pieszka, M. \& Borowicz, T. (2006). Probiotyki w żywieniu prosiąt. Wiadomości Zootechniczne, [Probiotics in pigs nutrition. Zootechnical Message] Vol. R.XLIV, pp. 1-39, ISSN 0209-2492 [in Polish]

Jin, L.Z.; Ho, Y.W.; Abdullah, N.; Ali, M.A. \& Jalaludin, S. (1998). Effects of adherent Lactobacillus cultures on growth, weight of organs and intestinal microflora and volatile fatty acids in broilers. Animal Feed Science and Technology, Vol. 70, pp. 197209, ISSN 0377-8401

Klaenhammer, T.R. (1993). Genetics of bacteriocins produced by lactic acid bacteria. FEMS Microbiology Review, Vol. 12, pp. 39-86, ISSN 0168-6445

Kralik, G.; Milaković, Z. \& Ivanković, S. (2004). Effect of probiotic supplementation on the performance and the composition of the intestinal microflora in broilers. Acta Agraria Kaposváriensis, Vol. 8, No. 2, pp. 23-31, ISSN 1418-1789

Lillehoj, H.S. \& Trout, J.M. (1996). Avian gut-associated lymphoid tissues and intestinal immune responses to Eimerica parasites. Clinical Microbiology Reviews, Vol. 9, pp. 349-360, ISSN 0893-8512

Lilly, D.M. \& Stillwell, R.H. (1965). Probiotics: Growth promoting factors produced by microorganisms. Science, Vol. 147, pp. 747-748, ISSN 0036-8075 
Lipiński, K. (2007). Żywieniowe strategie zapobiegania nekrotycznemu zapaleniu jelit. Hodowca drobiu, [The nutritional strategies of prevention the enteritis. Poultry farmer's] Vol. 2, pp. 5-17, ISSN 1425-963X [in Polish]

Mahdari, A.H.; Rahmani, H.R. \& Pourreza, I. (2005). Effect of probiotic supplements on egg quality and laying hen's performance. International Journal of Poultry Science, Vol. 4, No. 7, pp. 488-492, ISSN 16828356

Maiolino, R.; Fioretii, A.; Menna, L.F. \& Meo, C. (1992). Research on the efficiency of probiotics in diets for broiler chickens. Nutrition Abstracts and Reviews Series B, Vol. 62, pp. 482, ISSN 0029-6619

Mercenier, A.; Pavan, S. \& Pot, B. (2003). Probiotics as biotherapeutic agents: Present knowledge and future prospects. Current Pharmaceutical Design, Vol. 9, No. 2, pp. 175-191, ISSN 1381-6128

Messens, W. \& de Vuyst, L. (2002). Inhibitory substances produced by Lactobacilli isolated from sourdough - a review. International Journal of Food Microbiology, Vol. 72, No. 1, pp. 31-43, ISSN 0168-1605

Michałowski, P., Libudzisz, Z., Śliżewska, K., Klewicka, E., Motyl, I. \& Zabierski, R. (2004). Probiotic growth promoter for poultry. Licence Number P-371363

Mitterdorfer, G.; Mayer, H.K.; Kneifel, W. \& Viernstein, H. (2002). Clustering of Saccharomyces boulardii strains within the species $S$. cerevisiae using molecular typing techniques. Journal of Applied Microbiology, Vol. 18, pp. 521-530, ISSN 1364-5072

Mountzouris, K.C.; Tsirtsikos P.; Kalamara E.; Nitsch S.; Schatzmayr, G. \& Fegeros, K. (2007). Evaluation of the Efficacy of a Probiotic Containing Lactobacillus, Bifidobacterium, Enterococcus, and Pediococcus Strains in Promoting Broiler Performance and Modulating Cecal Microflora Composition and Metabolic Activities. Poultry Science, Vol. 86, pp. 309-317, ISSN 0032-5791

Nousiainen, J.; Jaranainen, P.; Setala, J. \& von Wright, A. (2004). Lactic acid bacteria as animal probiotics. Food Science and Technology, Vol. 139, pp. 547-580, ISSN 0023-6438

Oatley, J.T.; Rarick, M.D.; Ji, G.E. \& Linz, J.E. (2000). Binding of aflatoxin B1 to Bifidobacteria in vitro. Journal of Food Protection, Vol. 63, No. 8, pp. 1133-1136, ISSN 0362-028X

Ouwehand, A.C. \& Vesterlund, S. (2004). Antimicrobial components from lactic acid bacteria. Food Science and Technology, Vol. 139, pp. 375-396, ISSN 0023-6438

Parker, R.B. (1974). Probiotics, the other half of the antibiotic story. Animal Nutrition and Health, Vol. 29, pp. 4-8, ISSN 0003-3553

Ray, B. (1992). Food and microorganisms of concern. In: Food biopreservatives of Microbial Origin, B. Ray \& M. Daeschel (Ed.), pp. 103-197, Floryda, ISBN 0849349435, CRC Press

Ross, G.R.; Gusils, C. \& Gonzalez, S.N. (2008). Microencapsulation of probiotic strains for swine feeding. Biological and Pharmaceutical Bulletin, Vol. 31, No. 11, pp. 2121-2125, ISSN 0918-6158

Ross, G.R.; Gusils, C.; Oliszewski, R.; de Holgado, S.C. \& González, S.N. (2010). Effects of probiotic administration in swine. Journal of Bioscience and Bioengineering, Vol. 109, No. 6, pp. 545-549, ISSN 1389-1723

Saarela, M.; Mogensen, G.; Fonden, R.; Matto, J. \& Mattila-Sandholm, T. (2000). Probiotic bacteria: safety, functional and technological properties. Journal of Biotechnology, Vol. 84, No. 3, pp. 197-215, ISSN 0168-1656

Salminen, S.; von Wright, A.; Morelli, L.; Marteau, P.; Brassart, D.; de Vos, W.M.; Fondén, R.; Saxelin, M.; Collins, K.; Mogensen, G.; Birkeland, S.E. \& Mattila-Sandholm, T. (1998). Demonstration of safety of probiotics - a review. International Journal of Food Microbiology, Vol. 44, No 1-2, pp. 93-106, ISSN 0168-1605 
Schillinger, R.G. \& Holzapfel, W.H. (1996). Potential of antagonistic microorganisms and bacteriocins for the biological preservation of food. Trends in Food Science $\mathcal{E}$ Technology, Vol. 7, pp. 158-164, ISSN 0924-2244

Sharma, R.P. (1993). Immunotoxicity of mycotoxins. Journal of Dairy Science, Vol. 76, pp. 892897, ISSN 2044-2432

Shetty, P.H. \& Jespersen, L. (2006). Saccharomyces cerevisiae and lactic acid bacteria as potential mycotoxin decontaminating agents. Trends in Food Science and Technology, Vol. 17, pp. 48-55, ISSN 0924-2244

Smulikowska, S.; Śliżewska, K.; Biernasiak, J.; Mieczkowska, A. \& Michałowski, P. (2005). The effect of a probiotic composed of Lactobacillus and yeasts, and of flavomycin on the performance and faecal microflora of broiler chickens. Journal of Animal and Feed Sciences, Vol. 14, pp. 483-485, ISSN 1230-1388

Ŝtyriak, I.; Čonková, E.; Kmet, V.; Böhm, J. \& Razzazi, E. (2001). The use of yeast for microbial degradation of some selected mycotoxin. Mycotoxin Research, Vol. 174, No. 2, pp. 24-27, ISSN 0178-7888

Tasteyre, A.; Barc, M.C.; Karjalainen, T.; Bourlioux, P. \& Collignon, A. (2002). Inhibition of in vitro cell adherence of Clostridium difficile by Saccharomyces boulardii. Microbial Pathogenesis, Vol. 32, pp. 219-225, ISSN 0882-4010

Tomas, M.S.; Otero, C.M.; Ocana, V. \& Nader-Macias, E.M. (2004). Production of antimicrobial substances by lactic acid bacteria I: determination of hydrogen peroxide. Methods in Molecular Biology, Vol. 268, pp. 337-346, ISSN 1064-3745

Turner, J.L.; Pas, S.; Dritz, S. \& Minton, J.E. (2002). Alternatives to conventional antimicrobials in swine diets. Professional Animal Scientists, Vol. 17, pp. 217-226, ISSN 1080-7446

Van der Aa Kühle, A.; Skovgaard, K. \& Jespersen, L. (2005). In vitro screening of probiotic properties of Saccharomyces cerevisiae var. boulardii and food-borne Saccharomyces cerevisiae strains. International Journal of Food Microbiology, Vol. 101, No. 1, pp. 29-39, ISSN 0168-1605

Vergin, F. (1954). Anti- und Probiotika. Hipokrates, Vol. 25, pp. 16-119, ISSN 0018-2001

Watkins, B.A. \& Kratzer, F.H. (1983). Effect of oral dosing of Lactobacillus strains on gut colonization and liver biotin in broiler chicks. Poultry Science, Vol. 62, pp. 2088-2094, ISSN 0032-5791

Watkins, B.A. \& Kratzer, F.H. (1984). Drinking water treatment with commercial preparation of a concentrated Lactobacillus culture for broiler chickens. Poultry Science, Vol. 63, pp. 1671-1673, ISSN 0032-5791

Witte, W. (2000). Ecological impact of antibiotic use in animals on different complex microflora: environment. International Journal of Antimicrobial Agents, Vol. 14, No. 4, pp. 321-325, ISSN 0924-8579

Yiannikouris, A. \& Jouany, J.P. (2002). Mycotoxins in feeds and their fate in animals: a review. Animal Research, Vol. 51, pp. 81-99, ISSN 0367-6722 


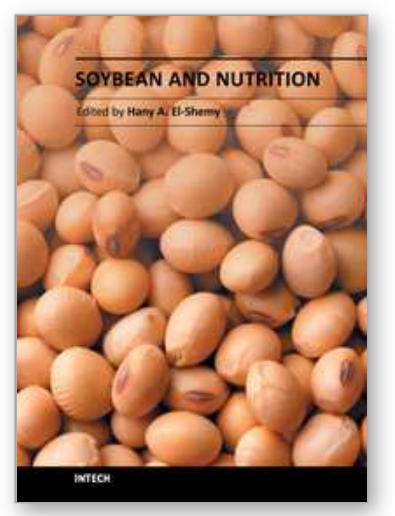

\author{
Soybean and Nutrition \\ Edited by Prof. Hany El-Shemy
}

ISBN 978-953-307-536-5

Hard cover, 476 pages

Publisher InTech

Published online 12, September, 2011

Published in print edition September, 2011

Worldwide, soybean seed proteins represent a major source of amino acids for human and animal nutrition. Soybean seeds are an important and economical source of protein in the diet of many developed and developing countries. Soy is a complete protein and soy-foods are rich in vitamins and minerals. Soybean protein provides all the essential amino acids in the amounts needed for human health. Recent research suggests that soy may also lower risk of prostate, colon and breast cancers as well as osteoporosis and other bone health problems and alleviate hot flashes associated with menopause. This volume is expected to be useful for student, researchers and public who are interested in soybean.

\title{
How to reference
}

In order to correctly reference this scholarly work, feel free to copy and paste the following:

Joanna Biernasiak, Katarzyna Sliżewska and Zdzisława Libudzisz (2011). Feeds with Probiotics in Animals' Nutrition, Soybean and Nutrition, Prof. Hany El-Shemy (Ed.), ISBN: 978-953-307-536-5, InTech, Available from: http://www.intechopen.com/books/soybean-and-nutrition/feeds-with-probiotics-in-animals-nutrition

\section{INTECH}

open science / open minds

\section{InTech Europe}

University Campus STeP Ri

Slavka Krautzeka 83/A

51000 Rijeka, Croatia

Phone: +385 (51) 770447

Fax: +385 (51) 686166

www.intechopen.com

\section{InTech China}

Unit 405, Office Block, Hotel Equatorial Shanghai

No.65, Yan An Road (West), Shanghai, 200040, China

中国上海市延安西路65号上海国际贵都大饭店办公楼405单元

Phone: +86-21-62489820

Fax: +86-21-62489821 
(C) 2011 The Author(s). Licensee IntechOpen. This chapter is distributed under the terms of the Creative Commons Attribution-NonCommercialShareAlike-3.0 License, which permits use, distribution and reproduction for non-commercial purposes, provided the original is properly cited and derivative works building on this content are distributed under the same license. 